IP Periodica Polytechnica

Social and Management

Sciences

25(2), pp. 87-96, 2017

https://doi.org/10.3311/PPso.9758

Creative Commons Attribution (i)

RESEARCH ARTICLE

\section{Are Managers in Slovakia Ethical Leaders? Key Findings on the Level of Ethical Leadership in the Slovak Business Environment}

\author{
Anna Lašáková ${ }^{1}$, Anna Remišová ${ }^{1}, Z$ uzana Kirchmayer ${ }^{1}$
}

Received 18 July 2016; accepted 02 November 2016

\begin{abstract}
Ethical leadership is a highly relevant and up-to-date topic in management studies because it represents a genuine key to improved work environment. To date, there was a considerable lack of empirical data on this specific leadership approach especially in the Central and Eastern European part of the world. This article represents an original and novel contribution to the respective field with preliminary results of an extensive ethical leadership research in the Slovak business environment carried out on the sample of 810 managers. Based on exploratory research design, results point out that ethical leadership is just moderately embedded in the current Slovak management practice and leaders do not utilize the full potential of ethics management tools at workplace. Still, there are some interesting commonalities and differences in the level of ethical leadership across the Slovak sample regarding the regional company location, company ownership, and company size.
\end{abstract}

\section{Keywords}

leadership, ethical leadership, moral person, moral manager, Ethical Leadership Scale (ELS), Slovakia

\footnotetext{
${ }^{1}$ Department of Management, Faculty of Management, Comenius University in Bratislava, Odbojárov 10, 82005 Bratislava, Slovakia

*Corresponding author, e-mail: anna.lasakova@fm.uniba.sk
}

\section{Introduction}

Ethical leadership is one of the top topics within the business ethics-oriented management studies. After the recent economic crisis rooted in morally questionable management practices, interest in ethical leadership has expanded rapidly in the scientific literature. The trend of abandonment of a traditional instrumental view of leadership and commencement to a new humanistic management of employees is quite robust in the current scientific discourse. Ethical leadership is being investigated from both a theoretical perspective (for e.g. Fehr et al., 2015; Lawton and Paez, 2015; Price, 2008; Brown and Trevino, 2006) and from an empirical angle (for e.g. Yukl et al., 2013; Kalshoven et al., 2011; Riggio et al., 2010; Brown et al., 2005). Studies focusing on the positive consequences of ethical leadership are also numerous (for e.g. Xu et al., 2014; Babalola et al., 2014; Mayer et al., 2012; Elci et al., 2012; Den Hartog and Belschak, 2012; Neubert et al., 2009; Toor and Ofori, 2009).

In this context it is important to note that these kinds of studies are quite rare in the countries of the Central and Eastern Europe (CEE). We consider it vital to address the ethical side of management in the transitional CEE countries, where people have to face not only economic, legal and cultural transitions but also a shift in their morality systems. In this process of morality transition a special attention should be paid to the role of business organizations in improving ethical behaviour. However, still, there is a growing number of scandals witnessed in the business arena, most of all due to continuous ethical failures of managers like the corruption in private and public sectors (Beddow, 2016; Batory, 2012; De Ridder, 2009), or ineffective HRM practices (Järvalt and Randma-Liiv, 2010) and related mistreatment of employees (Lašáková et al., 2016). As Kuralt (2008) has noted, societal transition represents a radical social change, and as such it embodies a special challenge to managers.

To address the aforementioned challenges, this article integrates current knowledge on ethical leadership and its desirable consequences for work environment. First, the concept of ethical leadership is delineated. We shed light also on some of the positive organizational outcomes related to ethical leadership. Next, the methodological approach to the research of 
ethical leadership in Slovakia is presented. Deriving from this methodological clarification, research results are outlined. The closing part addresses discussion to research outcomes as well as the main limitations of our approach and summarizes shortly the current challenges of ethical leadership in Slovakia. This research is, to our knowledge, one of the first attempts to systematically measure the level of ethicality in leadership in the $\mathrm{CEE}$ region. Thus we provide novel insights into this topic as well as a ground for further comparative research.

\section{Nature and consequences of ethical leadership}

The present study derives from the idea of Trevino et al. (2000) that ethical leadership presupposes both personal integrity and ethical management. Ethical leader acts as a moral person and a moral manager. Besides meeting ethical virtues like honesty, objectivity, or trustworthiness, ethical leader acts as a moral manager at workplace; utilizing formal sources of power and thus instilling clear ethical standards for employee behaviour, acknowledging ethical behaviour and disciplining for deviance. In their next study, Brown and Trevino (2006) note that ethical leader is someone who often discusses ethics with others and explains the importance of ethical conduct in business.

Consequently, we assume that ethical leaders follow universal ethical principles both in their private and professional life (Lašáková et al., 2015). The core of ethical leadership lies in the purposeful guidance of other people based on ethical principles and taking into account the consequences of acts to not to harm others. Decisions and actions of an ethical leader are guided by universal ethical principles of honesty, trustworthiness, considerateness, responsibility and justice (Remišová and Lašáková, 2013). In our conception we assume that it is important to not only consider the ethical motive and ethical actions but also the ethical quality of the means that are utilized in order to reach the desired goals. As such, ethical leadership contraposes the idea that good ends can be reached by bad means. Put differently, ethical leadership can be delineated as a leadership that stems from ethical principles and at the same time it does not harm any stakeholders. Hence, leadership should pass the test of both deontological ethics and teleological ethics (Remišová et al., 2016).

Although there is no consensus in the literature on what is ethical leadership, a growing number of authors accept the original idea of Brown, Trevino and Harrison that substantial in leadership is "the demonstration of normatively appropriate conduct through personal actions and interpersonal relationships, and the promotion of such conduct to followers through two-way communication, reinforcement, and decision-making" (Brown et al., 2005, p. 120). This definition is based on the social learning theory, proposing that leaders influence the ethical conduct of followers primarily via role modelling. Followers observe, learn from, imitate, and eventually collude with their leader. Through role modelling employees can learn what kind of behaviour is likely to be expected, rewarded, or disciplined in company. As Brown et al. (2005) put it, leaders are a source of such modelling because of their assigned role, rank and accomplishments, and their power to influence the behaviour and outcomes of others. Further, as Jordan et al. (2013) found out in their research, leaders higher than their followers in cognitive moral development (advanced moral reasoners) are perceived by their followers as significant ethical role models whose behaviour and reactions draw followers' attention.

From a more critical standpoint, Eisenbeiss (2012) analyses the vagueness and the Western-based perspective that is being applied onto the ethical leadership concept in the current leadership discourse. Using a normative, integrative and interdisciplinary approach, Eisenbeiss (2012) concludes that ethical leadership is based on four orientations. First, humane orientation to treat others with dignity and respect, second, justice meaning to make fair and consistent decisions, third, sustainability and responsibility based on leaders' long-term views on success and their concern for the welfare of society and the environment, and finally, the moderation orientation to temperance and humility and balanced leader behaviours. Indeed, modesty is an important ingredient of ethical leadership. For instance, Lorincová and Lelková (2016) come to conclusion that high level of self-confidence predicts higher level of manipulation in Machiavellian leaders at workplace.

De Hoogh and Den Hartog take a different stance, namely the corporate social responsibility perspective and define ethical leadership as the process of influencing the activities of a group toward goal achievement in a socially responsible way (De Hoogh and Den Hartog, 2009 acc. to Den Hartog, 2015). Subsequently, Kalshoven et al. (2011) conceptualize ethical leadership in a model of seven leadership behaviours: fairness, integrity, ethical guidance, people orientation, power sharing, role clarification, and concern for sustainability. These seven behavioural patterns form together a multi-dimensional construct for measuring ethical leadership in organizations titled Ethical leadership at work.

In sum, ethical leadership studies show a tendency to diverge over time rather than to converge in regard to categories and terms used. To add to noise in this plethora of notions, new terms emerge, or old terms are re-introduced into this discourse. For instance, Wright and Quick (2011) bring in the term "character-based leadership", Riggio et al. (2010) propose a "virtuebased" leadership approach, and Fehr et al. (2015) introduce the "moralized leadership" term. All of the above mentioned concepts regard ethical leadership explicitly or implicitly as a deliberate process. To contrast this prominent idea and to add a fresh insight into the ethical leadership literature, Weaver et al. (2014) conceive the moral intuition as a foundation, based on which leaders act ethically. Their article points out that ethical leadership could be conceptualized as not purely an intendedly rational process. 
The current popularity of the ethical leadership concept is triggered by a wide array of positive organizational outcomes which ethical leadership can produce in the work environment. For instance, it is assumed that ethical leadership is interconnected with CSR-oriented values and positive organizational behaviours that capitalize on "positively oriented human resource strengths and psychological capacities that can be measured, developed, and effectively managed for performance improvement in today's workplace" (Luthans, 2002).

In this context, Yazdani and Murad (2015) theorize on the need to overcome the short-term and short-sighted management commitment for the achievement of solely economic goals, which causes businesses to be decoupled from the rest of society, thus creating self-contained worlds. They assume that trust among employees that is based on ethical conduct is an essential precondition for achieving a sustainable competitive advantage. Similarly, also Lačný (2013) emphasizes that mutual trust between employees is a prerequisite for the voluntary identification of employees with the organization, its goals and vision. Interestingly, ethical leadership contains all major factors that are related to employee work-life balance, such as good relations with supervisor, pleasant atmosphere at workplace, open communication and active listening to the needs of employees (on WLB see for instance Robak et al., 2016).

In terms of top management, De Hoogh and Den Hartog (2008) point out that the ethical conduct of leaders is linked with the perceived effectiveness of top management and optimism of subordinates regarding their future in the company as well as in regard to the future of the company as a whole. Correspondingly, Mayer et al. (2009) assume that the basic pillar of an ethical organizational culture is an ethical senior management, because the top management sets a tone for the rest of the company. This "tone on the top" affects the ethical behaviour of lower-level managers.

As for positive effects on workforce stability, Den Hartog and Belschak (2012) suggested in their research that the ethical leadership is connected to employee initiative with work engagement acting as a mediator in this relationship. Elci et al. (2012) found out that ethical leadership negatively affects turnover intention of employees. Correspondingly, also Babalola et al. (2014) stated that ethical leadership moderates the relationship between frequent change and employee turnover intention, while this relation was positive only when ethical leadership was low. In addition, Hassan et al. (2013) found out that ethical leadership reduces employee absenteeism and has a positive effect on employee loyalty to the organization.

Further, Mayer et al. (2012) confirmed the negative relationship between ethical leadership and unit unethical behaviour and relationship conflict. Within a "full range leadership model", Toor and Ofori (2009) provided evidence in their research that ethical leadership was positively and significantly associated with transformational leadership, transformational culture of organization, contingent reward dimension of transactional leadership, leader effectiveness, employee willingness to put in extra effort, and employee satisfaction with the leader.

And finally, in terms of employee well-being, $\mathrm{Xu}$ et al. (2014) confirmed that ethical leadership stimulates employees' trust in their employing organization, which in turn promotes their justice perceptions toward the organization. According to a study done by Avey et al. (2012), ethical leadership affects the feeling of well-being of employees and their job satisfaction. Employees are under the guidance of an ethical leader optimistic, confident and realize that they have an impact on what is happening in the company.

\section{Research methodology 3.1 Sample}

In sum, 810 respondents participated in our research. The sample consisted of Slovaks on various managerial positions in organizations. Our sampling strategy was based on several criteria of stratification of managerial personnel, being it the three management levels (top management, middle management and line management), gender and age of respondents, private and public ownership and size of the companies involved in the research, and Slovak regions where companies operate.

Approximately $70 \%$ of the respondents were working in the Bratislava region. Further, 58.3\% was employed in a foreignowned company, and $45.3 \%$ of the sample stated to work in a large company with more than 250 employees. Almost $23 \%$ worked for medium-sized companies with 50 - 249 employees, $19.6 \%$ in small companies with $10-49$ employees, and $10.5 \%$ stated to work in a micro-sized companies with less than 10 employees. Obtained data were transcribed in an Excel worksheet and then recoded in the SPSS program for the aim of further statistical analysis.

\subsection{Method}

For the purposes of investigation of the level of ethical leadership, the respondents were asked to assess their immediate supervisors on a seven-point scale via the Ethical Leadership Scale (ELS), which was developed by Brown et al. (2005). This instrument was double-blind language checked in the process of translation from English to Slovak language. Further, the internal reliability of the Slovak version of the scale was checked, too. The Cronbach's alpha was equal to 0.938 , proving that in the Slovak context the ELS had a high level of internal reliability.

The ELS comprises ten items that describe behavioural patterns of ethical leadership and personality characteristics of an ethical leader (Brown et al., 2005, p. 125): Listens to what employees have to say; Disciplines employees who violate ethical standards; Conducts his/her personal life in an ethical manner; Has the best interests of employees in mind; Makes fair and balanced decisions; Can be trusted; Discusses business 
Table 1 Overall level of ethical leadership in Slovakia

\begin{tabular}{|c|c|c|c|c|c|c|c|}
\hline & $\mathrm{N}$ & Min. & Max. & Mean & Std. dev. & $\begin{array}{l}\text { Skewness } \\
\text { Stat.\& St.error }\end{array}$ & $\begin{array}{l}\text { Kurtosis } \\
\text { Stat.\& St.error }\end{array}$ \\
\hline Overall level of ethical leadership & 791 & 1 & 7 & 5.07 & 1.347 & -.812 & .011 \\
\hline
\end{tabular}

Note: Mean values of responses on the scale one to seven, one indicating low level of ethical leadership and seven representing high level of ethical leadership.

Table 2 Results for ten ELS items

\begin{tabular}{lllll}
\hline ELS items & $\begin{array}{l}\text { Listens to what } \\
\text { employees have to say }\end{array}$ & $\begin{array}{l}\text { Disciplines employees } \\
\text { who violate ethical } \\
\text { standards }\end{array}$ & $\begin{array}{l}\text { Has the best interests of } \\
\text { employees in mind }\end{array}$ & $\begin{array}{l}\text { Makes fair and balanced } \\
\text { decisions }\end{array}$ \\
\hline Mean & 5.60 & 4.51 & 5.24 & 5.26 \\
\hline St.dev. & 1.514 & 1.833 & 1.575 & 1.556 \\
\hline ELS items & $\begin{array}{l}\text { Discusses business ethics } \\
\text { or values with employees }\end{array}$ & $\begin{array}{l}\text { Sets an example of how } \\
\text { to do things the right way } \\
\text { in terms of ethics }\end{array}$ & $\begin{array}{l}\text { Defines success not } \\
\text { just by results but also } \\
\text { the way that they are } \\
\text { obtained }\end{array}$ & $\begin{array}{l}\text { When making decisions, } \\
\text { asks "what is the right } \\
\text { thing to do?" }\end{array}$ \\
\hline Conducts his/her personal \\
life in an ethical manner
\end{tabular}

Note: Mean values of responses on the scale one to seven, one indicating low level of ethical leadership and seven representing high level of ethical leadership.

ethics or values with employees; Sets an example of how to do things the right way in terms of ethics; Defines success not just by results but also the way that they are obtained; When making decisions, asks "what is the right thing to do?". The ELS was conceived as a unidimensional scale for assessment of ethical leadership, although originally Trevino, Hartman and Brown (2000) theorized the ethical leadership consisting of two aspects, the moral manager and the moral person dimensions.

\subsection{Research questions}

Four research questions were outlined in line with the subject matter of this paper. First, there is a considerable lack of data on the level of ethical leadership in CEE countries. This does not allow for comparative international and intercultural studies in terms of ethicality of leadership practices. We have tackled this issue for the Slovak case and posited: RQ1: What is the overall level of ethical leadership in the Slovak business environment?

Second, to infer the data on ethical leadership in detail, we have inspected the potential regional differences in Slovakia. Since there are considerable regional disparities between Bratislava and other Slovak regions in terms of economics, the goal was to assess differences in the level of ethical leadership in the respective two samples, deriving from assumption that countries and regions with prosperous economies have correspondingly higher quality of life and accompanying ethical standards are applied throughout these societies. Henceforth, we have proposed: $R Q 2$ : Are there any statistically significant differences in the level of ethical leadership between companies in the Bratislava region and the rest of Slovakia?

Third, investors often bring in the culture and mentalityrelated patterns of employee behaviour into their subsidiaries.
Hypothesising that with financial inflow comes in also an (un) ethical inflow, we have asked whether: RQ3: Are there any substantial differences between the Slovak and foreign-owned companies in the level of ethical leadership?

Finally, theorizing that larger organizations have often a more structured and formalized internal environment, which instils clearer behavioural criteria for employees, and a sounder ethical infrastructure than in smaller companies, we have postulated: RQ4: Are there any statistically significant differences in the level of ethical leadership regarding the company size?

\section{Research results \\ 4.1 Level of ethical leadership}

Level of ethical leadership was identified based on calculation of the mean values of answers on the ten ELS items. The overall results for ethical leadership are shown in Table 1. Table 2 presents results for the ten separate ELS items. The results indicate that our respondents perceive their supervisors as leaders whose ethical leadership is on a slightly above average level. Managers live up to obligation to listen to what their employees have to say (5.60), they are trustworthy (5.55), they tend to make fair and objective decisions (5.26), and in their private life they behave in an ethical manner (5.23). On the other hand, some of the obligations linked to the ethical leadership concept are not so well fulfilled. Managers do not discipline so much others for unethical conduct (4.51), and they do not tend so much to ask themselves, what is the right thing to do, when they face a moral dilemma (4.61).

In sum, research results show that mangers are being perceived by their fellow subordinates as leaders, who are to a certain extend moral persons showing virtues of being fair, 
Table 3 Level of ethical leadership differentiated between Bratislava region and other Slovak regions

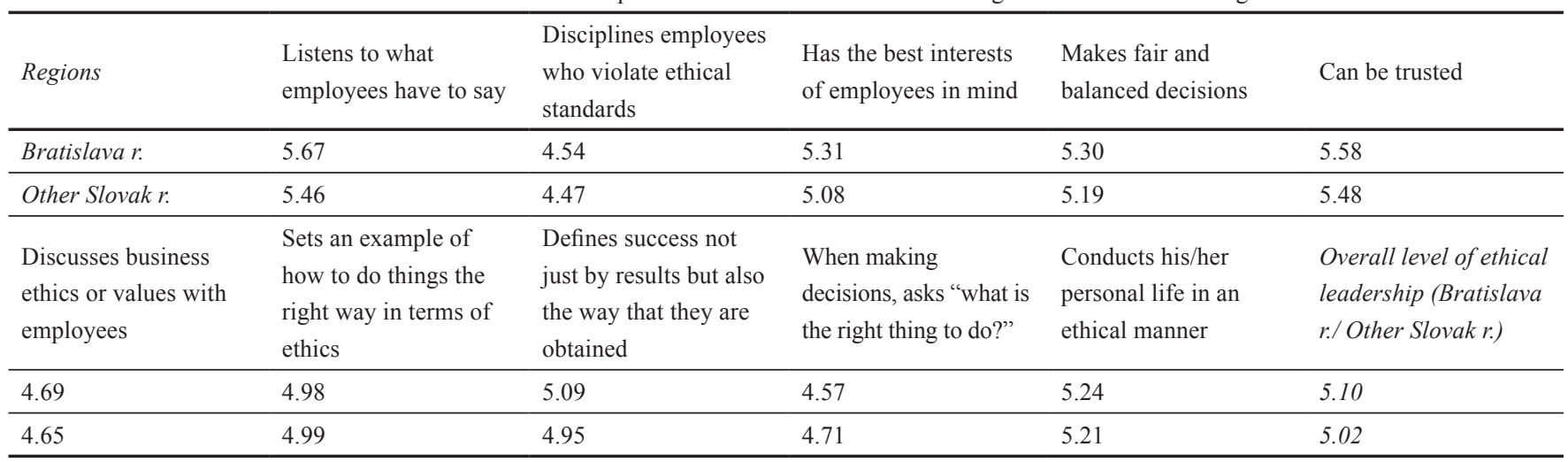

Note: Mean values of responses on the scale one to seven, one indicating low level of ethical leadership and seven representing high level of ethical leadership.

objective, and trustworthy. To a slightly lesser extent they are seen as moral managers, who actively care for ethics at workplace, instil certain directions that regulate the ethical behaviour of employees, discipline unethical behaviour of others, or discuss the importance of ethics at workplace.

\subsection{Slovak regions}

The comparative analysis that differentiated results according to Slovak regions showed that the overall level of ethical leadership is higher in the Bratislava region than in other Slovak regions (see Table 3 ).

However, after conducting the independent samples $t$ test analysis we came to conclusion that this difference was not proven to be statistically significant ( $\mathrm{p}>0.05$ ). Thus, level of ethical leadership does not differ substantially between companies in the Bratislava region and other Slovak regions.

\subsection{Company ownership}

After conducting the $t$ test analysis based on the ownership of companies, some interesting results were found. In general, foreign owned companies scored higher in ethical leadership than Slovak companies in all of the measured aspects; and significant differences $(p<0.05)$ were found in the overall level of ethical leadership as well as in five out of the ten ELS items (see Table 4).

These results provide a remarkable picture of the ethical quality of leadership process in companies operating in Slovakia. Level of ethical leadership differs considerably between companies with foreign ownership and Slovak ownership, the latter showing lower levels of ethical leadership. It seems that foreign companies cope with the ethical challenges of leadership better than the Slovak companies do. Although it is hard to unveil the reasons for this, our results point toward the fact that managers working in foreign owned companies tend to see their supervisors as more ethical persons as well as ethical managers than their Slovak counterparts.

\subsection{Company size}

The analysis of variance indicated two significant differences out of ten ELS items between the four groups that were differentiated according to the number of employees, that is micro companies with up to 9 employees, small companies with up to 49 employees, medium size companies with up to 249 employees and large companies with more than 250 employees (see Table 5).

Further statistical analysis based on the independent samples $t$ test revealed that there is a statistically significant difference between the large and other companies in disciplining employees who do not respect ethical standards set in the company $($ Sig. $=0.005)$. Managers in large companies scored significantly higher on this particular ELS item $($ Mean $=4.72)$ than managers in other companies (Mean $=4.35)$. It seems that considerable formalization of internal environment in these companies affects the ethical climate, resulting in higher level of formal reinforcement and accountability of the employee ethical behaviour.

Furthermore, when comparing micro organizations with the rest of our sample, it was proven that statistically significant difference was found in the level, to which managers are seen to make balanced and fair decisions (Sig. $=0.002)$. Interestingly, managers were perceived considerably more as leaders who are able to decide in an ethical manner in micro size companies $($ Mean $=5.78)$ than in larger companies $($ Mean $=5.21)$.

\section{Discussion}

This article fills in the gap in scientific studies of ethical leadership in that it offers a solid ground for further comparative research in this field. Current literature focuses more on uncovering antecedents and consequences of ethical leadership than on exploratory descriptive studies of the level and nature of ethical leadership in a country-based perspective. To our knowledge, this article is first to present findings on the level of ethical leadership in one of the CEE countries, in Slovakia, based on a standardized methodology for measuring the respective phenomenon. 
Table $4 \mathrm{~T}$ test results for significant differences in the level of ethical leadership in regard to company ownership (foreign and Slovak)

\begin{tabular}{|c|c|c|c|c|c|c|}
\hline ELS items & Ownership & Mean & $\mathrm{F}$ & $\mathrm{t}$ & df & Sig. \\
\hline \multirow[t]{2}{*}{ Listens to what employees have to say } & Foreign & 5.75 & 27.821 & 3.104 & 774 & $.002 * *$ \\
\hline & Slovak & 5.40 & & & & \\
\hline \multirow{2}{*}{$\begin{array}{l}\text { Disciplines employees who violate ethical } \\
\text { standards }\end{array}$} & Foreign & 4.67 & .648 & 2.864 & 769 & $.004 * *$ \\
\hline & Slovak & 4.29 & & & & \\
\hline \multirow[t]{2}{*}{ Has the best interests of employees in mind } & Foreign & 5.43 & 27.741 & 4.108 & 774 & $.000 * *$ \\
\hline & Slovak & 4.96 & & & & \\
\hline \multirow[t]{2}{*}{ Makes fair and balanced decisions } & Foreign & 5.34 & 7.980 & 1.564 & 773 & .118 \\
\hline & Slovak & 5.16 & & & & \\
\hline \multirow[t]{2}{*}{ Can be trusted } & Foreign & 5.63 & 12.114 & 1.694 & 769 & .091 \\
\hline & Slovak & 5.42 & & & & \\
\hline \multirow{2}{*}{$\begin{array}{l}\text { Discusses business ethics or values with } \\
\text { employees }\end{array}$} & Foreign & 4.77 & 6.348 & 1.644 & 772 & .101 \\
\hline & Slovak & 4.53 & & & & \\
\hline \multirow{2}{*}{$\begin{array}{l}\text { Sets an example of how to do things the } \\
\text { right way in terms of ethics }\end{array}$} & Foreign & 5.07 & 2.061 & 1.671 & 769 & .095 \\
\hline & Slovak & 4.85 & & & & \\
\hline \multirow{2}{*}{$\begin{array}{l}\text { Defines success not just by results but also } \\
\text { the way that they are obtained }\end{array}$} & Foreign & 5.15 & 7.113 & 2.091 & 772 & $.037^{*}$ \\
\hline & Slovak & 4.89 & & & & \\
\hline \multirow{2}{*}{$\begin{array}{l}\text { When making decisions, asks "what is the } \\
\text { right thing to do?" }\end{array}$} & Foreign & 4.70 & 4.045 & 1.942 & 771 & .052 \\
\hline & Slovak & 4.46 & & & & \\
\hline \multirow{2}{*}{$\begin{array}{l}\text { Conducts his/her personal life in an ethical } \\
\text { manner }\end{array}$} & Foreign & 5.34 & 6.634 & 2.442 & 763 & $.015^{*}$ \\
\hline & Slovak & 5.06 & & & & \\
\hline \multirow[t]{2}{*}{ Overall level of ethical leadership } & Foreign & 5.18 & 10.735 & 2.820 & 774 & $.005 * *$ \\
\hline & Slovak & 4.91 & & & & \\
\hline
\end{tabular}

Note: Mean values of responses on the scale one to seven, one indicating low level of ethical leadership and seven representing high level of ethical leadership; * significance at 0.05 level (2-tailed), ** significance at 0.001 level (2-tailed).

Table 5 ANOVA results for significant differences in mean values of four groups of organizations according to the number of employees

\begin{tabular}{|c|c|c|c|c|c|c|c|}
\hline \multicolumn{3}{|c|}{ ELS items * Size of organization } & \multirow{2}{*}{$\frac{\text { Sum of Squares }}{31.585}$} & \multirow{2}{*}{$\frac{\mathrm{df}}{3}$} & \multirow{2}{*}{$\frac{\text { Mean Square }}{10.528}$} & \multirow{2}{*}{$\frac{\mathrm{F}}{3.140}$} & \multirow{2}{*}{$\frac{\text { Sig. }}{.025 \%}$} \\
\hline \multirow{3}{*}{$\begin{array}{l}\text { Disciplines employees who } \\
\text { violate ethical standards }\end{array}$} & Between Groups & (Combined) & & & & & \\
\hline & Within Groups & & 2568.540 & 766 & 3.353 & & \\
\hline & Total & & 2600.125 & 769 & & & \\
\hline \multirow{3}{*}{$\begin{array}{l}\text { Makes fair and balanced } \\
\text { decisions }\end{array}$} & Between Groups & (Combined) & 23.131 & 3 & 7.710 & 3.254 & $.021 *$ \\
\hline & Within Groups & & 1824.508 & 770 & 2.369 & & \\
\hline & Total & & 1847.640 & 773 & & & \\
\hline
\end{tabular}

Note: * significance at 0.05 level (2-tailed).

Our research outcomes offer certain methodological and theoretical advancements to the ethical leadership studies. First, a snapshot of the current level of ethical leadership in Slovakia representing the CEE countries was revealed. Second, despite of big inter-regional economic disparities, no regional differences in terms of ethical leadership were unveiled in our research. Third, substantial positive influence of foreign-owned companies on the ethical quality of leadership throughout Slovakia was identified. And fourth, no remarkable variances in the level of ethical leadership were uncovered in respect to the company size; however, results indicate that a more formalized organizational environment in large companies might suppress the moral person-related leadership roles (leader's individual consideration and personalized approach toward employees).

In more detail, results point out that the ethical leadership in Slovakia is slightly above the arithmetic mean level with moderately high mean value of 5.07. Further, leaders are perceived more as moral persons and to a slightly lesser extent as moral managers. It seems that the role of ethical leaders to actively cope with ethics at workplace by deliberate utilization of managerial tools (rewards, punishments, control, active listening, etc.) is not so well developed than other ethical leadershiprelated roles in the Slovak context. 
In this respect, Brown and Trevino (2006) discuss on the prevalence of ethical leadership in business practice and conclude that there is a "discrepancy when the referent changes from perceptions of business leaders in general to direct experience with leaders in one's own organization". Media attract attention more to scandals of leaders' malpractices than to stories of good leaders who treat their subordinates well. They suggest that ethical leadership is not a rare phenomenon in organizations. Our results underpin their assertion to certain extend, too. The overall ELS score of 5.07 somewhat contradicts the hypothesis about a low level of ethical leadership in the contemporary corporate world.

Similarly to our findings, also other authors, who used the ELS tool, report a relatively high level for perceived ethical leadership. For instance, Piccolo et al. (2010) have used the ELS on a sample of 208 students from a large south-eastern university in the United States with a mean value of 5.13 on a seven-point scale. Stouten et al. (2010) reported on ELS mean value of 3.56 on a five-point scale, while their sample consisted of 825 respondents from a large consumer electronics factory in Belgium. Mayer et al. (2012) researched with ELS on a sample of 542 employees from a variety of organizations located in south-eastern United States with the 3.82 mean value for ethical leadership measured on a five-point scale. In China, Yidong and Xinxin (2013) tested five ELS items on a sample of 302 employees from two subsidiaries of two multi-national companies in Mainland China and arrived at the mean value of 3.44, again on a five-point Likert-type scale. In line with our results, all of the aforementioned findings suggest that the ethical leadership is not an uncommon phenomenon, at least in case respondents report via ELS on their direct supervisors.

Our findings tackled also regional differences in the level of ethical leadership. We have inspected the regional differences by comparing ethical leadership between the Bratislava region, which represents the most developed region with the lowest rate of unemployment (see for e.g. Matlovičová et al., 2014) and highest average nominal wage in Slovakia (see for e.g. Uramová and Kožiak, 2008) with the rest of Slovak regions. We found out that although the relative level of ethical leadership was higher in the Bratislava region, no significant differences were found in the level of ethical leadership in Bratislava region and other Slovak regions. Despite of the significant economic differences, in terms of leadership ethics in Slovakia no regional disparities were identified.

However, in comparing foreign-owned and Slovak-owned companies in our sample, the level of ethical leadership differs considerably. According to research outcomes, foreignowned companies exhibit substantially higher levels of ethical leadership than their Slovak counterparts. Thus, it seems that together with inflow of foreign capital also a sort of ethical inflow comes about. This interesting outcome opens a full range of possible interpretations. Managers in multinationals are usually subject of managerial professionalization that has, compared to somewhat undeveloped professionalization process in the CEE countries, a history. According to Sama and Shoaf (2008), profession is in a sense a "moral community" that enhances ethical behaviour of leaders. Professionalization is an effective tool for dissemination of moral values throughout the communities of professionals. Further, in general, multinationals have an elaborated ethical infrastructure of codes of ethics, reporting mechanisms, ethics bodies and formal managerial ethics education. These ethics program components introduce, develop and sustain moral values in the work environment in a systematic and longitudinal way. In addition, the design of organizational ethics program is based on ethics surveys, which provide managers with valuable information on ethical issues in their companies that have to be reflected in an ethics program. As Kaptein et al. (2005) note, ethics surveys do support effective ethical leadership. Surveys can reveal the extend and possible consequences of ethical misconduct in organizations and foremost, by introducing ethics surveys managers show their followers that ethics is, indeed, an important issue to them. As such, Kaptein et al. (2005) assume that to involve employees in ethics measurements demonstrates truly the idea of ethical leadership. Companies in Slovakia haven't got such a long tradition in ethics programs implementation as foreignowned, mostly multinationals (with headquarters located in Western part of the world) do. It is presumable that the above theorized "inflow of ethics" and related higher levels of ethical leadership identified in our research might be connected with a more ethically developed multinationals that have a longer tradition in ethics infrastructures than Slovak companies do. Also, the tradition to control the ethical conduct of managerial personnel, which is an indispensable part of ethics programs in organizations, could contribute to the identified differences between Slovak and foreign-owned companies.

Finally, also cross-cultural issue might play a role in these differences. However, it is hard to interpret these differences from a cultural framework, because adequate arguments from literature are missing. To explain differing levels of morality of nations by cultural predispositions is in social sciences a neglected and a tabooed issue. So, only few authors pay attention to this specific topic. As an exception, for instance Shao et al. (2013) carried out a meta-analysis and summarized data from 495 unique samples, representing over 190,000 employees working in 32 distinct countries and regions. Their results indicate that justice, as a classic ethical virtue, and its effects are strongest among nations associated with low power distance, individualism, femininity and uncertainty avoidance. These cultural traits are mostly typical for countries in the Western part of the world (Western Europe, USA), while high power distance, collectivism and masculinity characterize countries of the CEE region mostly (Bakacsi et al., 2002; on conceptual differences between Hofstede's and GLOBE intercultural dimensions see 
for instance Andó, 2008). Thus, the moral value of justice is more embedded in the western societies than in the eastern ones.

Formerly, we assumed that perhaps the size of companies in our sample would count for the difference in ethical leadership among foreign-owned and Slovak companies. Hence, looking for a feasible interpretation of this result, we controlled for the company size variable. However, only two major differences were identified in comparing levels of ethical leadership in regard to the company size. Leaders in large companies are sounder in disciplining employees for ethical misconduct (being it a "moral manager" attribute), while leaders in microsized companies with less than 10 employees are perceived as considerably more fair and balanced decision-makers (being it a "moral person" attribute) than the leaders in bigger companies are. Likely interpretation of this variance might be that the moral person-related leaders' roles are suppressed by a highly structured and formalized organizational environment of large companies with firmly articulated employee behaviour standards for ethics compliance and accountability. On the other hand, in work environment of small companies where for instance the HRM practices are likely not considerably structured, the moral manager-related roles have less room, in the sense that leaders in small companies have fewer opportunities to exercise formal ethics management. They rely mostly on the informal and somewhat less tangible ways of ethics development based on personal role modelling. Interestingly, these findings are in line with outcomes of Kalshoven and Boon (2012). Their study indicates that ethical leadership has a more significant role in fostering employee well-being when the HRM functions are weak than when employees perceive high levels of HRM. They theorize that when HRM is low, that is it provides fewer organizational resources to employees, an ethical leader can compensate this lack of guidance by being more helpful, fair supportive toward subordinates, which then has a positive influence on employee well-being. Correspondingly, also our findings indicate that a less formalized work environment facilitates leader's potential for personalized ethical approach to employees.

\section{Limitations and conclusion}

The basic limitation of our research lies in the nature of the sample that consisted only of managerial personnel. In this context it is important to note that results could differ if employees, who do not fulfil managerial responsibilities, would assess their superiors on the ELS. As Thoroughgood et al. (2012) note, subordinates might perceive their leaders as more ethical then they really are because of different motives. One might stem from the benefits they gain because of colluding with their leader. We assume that a significant proportion of our respondents could be promoted to managerial positions by their superiors. Therefore their evaluation of the level of ethical leadership performed by their supervisors might not reflect fully the true nature of the leadership. Nevertheless, measurement of ethical leadership via the ELS in other countries revealed that this scale has good psychometric qualities (see Rowold et al., 2009). High internal reliability of the scale was proven also in our research. Hence we assume that our results reflect accurately the ethical quality of leadership in Slovakia from the perspective of Slovak managers.

In conclusion, we attach great importance to the ethical leadership since we suggest that it represents a real key to a better working environment and indirectly also to an ethical society as a whole. Ethical conduct of managerial personnel serves as an indispensable prerequisite for companies to operate ethically and responsibly in respect to all stakeholders. If managers do not act as ethical leaders, it is doubtful, whether the company can fulfil corporate social responsibility-related obligations. At best, the ethical principles are then articulated to external communities just to market a good public image of the company. Without ethical leaders ethics cannot be develop at workplace. For this reason, we consider raising awareness and sensibility to the ethical conduct of managers to be an essential part of the ethical development in organizations. In this context, equally important is the higher education of the next generation of managers in business and managerial ethics.

\section{References}

Andó, I. (2008). Impact of business culture on empowerment. Periodica Polytechnica Social and Management Sciences. 16(1), pp. 13-20. https://doi.org/10.3311/pp.so.2008-1.02

Avey, J. B., Wernsing, T. S., Palanaski, M. E. (2012). Exploring the process of ethical leadership: The mediating role of employee voice and psychological ownership. Journal of Business Ethics. 107, pp. 21-34. https://doi.org/10.1007/s10551-012-1298-2

Babalola, M. T., Stouten, J., Euwema, M. (2014). Frequent change and turnover intention: The moderating role of ethical leadership. Journal of Business Ethics. https://doi.org/10.1007/s10551-014-2433-Z

Bakacsi, G., Takács, S., Karácsonyi, A., Imrek, V. (2002). Eastern European cluster: Tradition and transition. Journal of World Business. 37(1), pp. 69-80.

Batory, A. (2012). Why do anti-corruption laws fail in Central Eastern Europe? A target compliance perspective. Regulation \& Governance. 6, pp. 66-82. https://doi.org/10.1111/j.1748-5991.2011.01125.x

Beddow, R. (ed.). (2016). Corruption perceptions index 2015. Transparency International.

Brown, M. E., Trevino, L. K., Harrison, D. A. (2005). Ethical leadership: A social learning perspective for construct development and testing. Organizational Behavior and Human Decision Processes. 97(2), pp. 117-134. https://doi.org/10.1016/j.obhdp.2005.03.002

Brown, M. E., Trevino, L. (2006). Ethical leadership: A review and future directions. The Leadership Quarterly. 17(6), pp. 595-616. https://doi.org/10.1016/j.leaqua.2006.10.004

De Hoogh, A. H. B., Den Hartog, D. N. (2008). Ethical and despotic leadership, relationships with leader's social responsibility, top management team effectiveness and subordinates' optimism: A multi-method study. The Leadership Quarterly. 19(3), pp. 297-311. https://doi.org/10.1016/j.leaqua.2008.03.002 
De Ridder, E. (2009). EU aid for fighting corruption in the CzechRepublic and Slovakia: Where did it go wrong? Journal of Contemporary European Research. 5(1), pp. 61-81.

Den Hartog, D. N. (2015). Ethical leadership. The Annual Review of Organizational Psychology and Organizational Behavior. 2, pp. 409-434. https://doi.org/10.1146/annurev-orgpsych-032414-111237

Den Hartog, D. N., Belschak, F. D. (2012). Work engagement and Machiavellianism in the ethical leadership process. Journal of Business Ethics. 107(3), pp. 35-47. https://doi.org/10.1007/s10551-012-1296-4

Eisenbeiss, S. A. (2012). Re-thinking ethical leadership: An interdisciplinary integrative approach. The Leadership Quarterly. 23(5), pp. 791-808. https://doi.org/10.1016/j.leaqua.2012.03.001

Elci, M., Sener, I., Aksoy, S., Alpkan, A. (2012). The impact of ethical leadership and leadership effectiveness on employees' turnover intention: The mediating role of work related stress. In: 8th International Strategic Management Conference. Procedia - Social and Behavioral Sciences. 58, pp. 289-297. https://doi.org/10.1016/j.sbspro.2012.09.1003

Fehr, R., Yam, K. Ch., Dang, C. (2015). Moralized leadership: The construction and consequences of ethical leader perceptions. Academy of Management Review. 40(2), pp. 182-209. https://doi.org/10.5465/amr.2013.0358

Hassan, S., Wright, B. E., Yukl, G. (2013). Does ethical leadership matter in government? Effects on organizational commitment, absenteeism, and willingness to report ethical problems. Public Administration Review. 74(3), pp. 333-343. https://doi.org/10.1111/puar.12216

Järvalt, J., Randma-Liiv, T. (2010). Public sector HRM: The case of no central human resource strategy. Baltic Journal of Management. 5(2), pp. 242256. https://doi.org/10.1108/17465261011045142

Jordan, J., Brown, M. E. Trevino, L. K., Finkelstein, S. (2013). Someone to look up to: Executive-follower ethical reasoning and perceptions of ethical leadership. Journal of Management. 39(3), pp. 660-683. https://doi.org/10.1177/0149206311398136

Kalshoven, K., Boon, C. T. (2012). Ethical leadership, employee well-being, and helping. The moderating role of human resource management. Journal of Personnel Psychology. 11(1), pp. 60-68. https://doi.org/10.1027/1866-5888/a000056

Kalshoven, K., Den Hartog, D. N., De Hoogh, A. H. B. (2011). Ethical leadership at work questionnaire (ELW): Development and validation of a multidimensional measure. The Leadership Quarterly. 22(1), pp. 51-69. https://doi.org/10.1016/j.leaqua.2010.12.007

Kaptein, M., Huberts, L., Avelino, S., Lasthuizen, K. (2005). Demonstrating ethical leadership by measuring Ethics. A survey of U.S. public servants. Public Integrity. 7(4), pp. 299-312. https://doi.org/10.1080/10999922.2005.11051286

Kuralt, B. (2008). The professional ethics of Slovene management in light of globalization processes and historical heritage. Management. 13(2), pp. 81-91.

Lačný, M. (2013). Values as motivation factors of economic behavior. Journal of Economic Development, Environment and People. 2(4), pp. 74-83.

Lašáková, A., Remišová, A., Kirchmayer, Z. (2016). Key findings on unethical leadership in Slovakia. In:Proceedings of the 1st International Conference Contemporary Issues in Theory and Practice of Management 2016, pp. 252-260. Częstochowa, Wydawnictwo Wydziału Zarządzania Politechniki Częstochowskiej. 2016.

Lašáková, A., Remišová, A., Búciová, Z. (2015). Teoretická reflexia etického vedenia l'udí. (Theoretical reflection of ethical leadership.) In: Aktuálne problémy podnikovej sféry 2015, pp. 348-357. Bratislava, Ekonóm. 2015. (in Slovak)

Lawton, A., Paez, I. (2015). Developing a Framework for Ethical Leadership. Journal of Business Ethics. 130(3), pp 639-649.

https://doi.org/10.1007/s10551-014-2244-2
Lorincová, T., Lelková, A. (2016). Prediction of manipulation, empathy and social irritability through selected personality traits among managers. Periodica Polytechnica Social and Management Sciences. 24(2), pp. 83-87. https://doi.org/10.3311/PPso.8765

Luthans, F. (2002). The need for and meaning of positive organizational behavior. Journal of Organizational Behavior. 26, pp. 695-706. https://doi.org/10.1002/job.165

Matlovičová, K., Gaval’ová, A., Kolesárová, J. (2014). Regional disparities and their mitigation in Slovakia: Selected features and approaches. Revista Română de Geografie Politică, XVI(2), pp. 99-118.

Mayer, D. M., Kuenzi, M., Greenbaum, R., Bardes, M., Salvador, R. (2009). How low does ethical leadership flow? Test of a trickle-down model. Organizational Behavior and Human Decision Processes. 108(1), pp. 1-13. https://doi.org/10.1016/j.obhdp.2008.04.002

Mayer, D. M., Aquino, K., Greenbaum R. L., Kuenzi, M. (2012). Who displays ethical leadership and why does it matter? An examination of antecedents and consequences of ethical leadership. Academy of Management Journal, 55(1), pp. 151-171. https://doi.org/10.5465/amj.2008.0276

Neubert, M. J., Carlson, D. S., Kacmar, K M., Roberts, J. A., Chonko, L. B. (2009). The virtuous influence of ethical leadership behavior: Evidence from the field. Journal of Business Ethics. 90, pp. 157-170. https://doi.org/10.1007/s10551-009-0037-9

Piccolo, R. F., Greenbaum, R., den Hartog, D. N., Folger, R. (2010). The relationship between ethical leadership and core job characteristics. Journal ofOrganizational Behavior. 31, pp. 259-278.

https://doi.org/10.1002/job.627

Price, T. L. (2008). Kant's advice for leaders: "No, you aren't special". The Leadership Quarterly. 19(4), pp. 478-487. https://doi.org/10.1016/j.leaqua.2008.05.005

Remišová, A., Lašáková, A. (2013). K pojmom vedenie l'udí a etické vedenie l'udí. (On the notions of leadership and ethical leadership.) In:Manažment v 21. storočí: Problémy a východiská, pp. 283-293. Trenčín, Vysoká škola manažmentu. 2013. (in Slovak)

Remišová, A.. Lašáková, A., Rudy, J., Sulíková, A., Kirchmayer, Z., Fratričová, J. (2016). Ethical leadership in Slovak business environment. Wolters Kluwer, Praha. 2016.

Riggio, R. E., Zhu, W., Reina, C., Maroosis, J. A. (2010). Virtue-based measurement of ethical leadership: The leadership virtues questionnaire. Consulting Psychology Journal: Practice and Research. 62(4), pp. 235-250.

Robak, E., Słocińska, A., Depta, A. (2016). Work-life balance factors in the small and medium-sized enterprises. Periodica Polytechnica Social and Management Sciences. 24(2), pp. 88-95.

https://doi.org/10.3311/PPso.8871

Rowold, J., Borgmann, L., Heinitz, K. (2009). Ethical leadership: Psychometric properties of a German adaptation of Brown et al. (2009) Ethical Leadership Scale (ELS-D). Zeitschrift fur Arbeits-und Organisationpsychologie. 53(2), pp. 57-69. https://doi.org/10.1026/0932-4089.53.2.57

Sama, L. M., Shoaf, V. (2008). Ethical leadership for the professions: Fostering a moral community. Journal of Business Ethics. 78(1), pp. 39-46. https://doi.org/10.1007/s10551-006-9309-9

Shao, R., Rupp, D. E., Skarlicki, D. P., Jones, K. S. (2013). Employee justice across cultures: A meta-analytic review. Journal of Management. 39(1), pp. 263-301. https://doi.org/10.1177/0149206311422447

Stouten, J., Baillien, E., den Broeck, A. V., Camps, J., De Witte, H., Euwema, M. (2010). Discouraging bullying: The role of ethical leadership and its effects on the work environment. Journal of Business Ethics. 95, pp. 17.27. https://doi.org/10.1007/s10551-011-0797-x

Trevino, L. K., Hartman, L. P., Brown, M. (2000). Moral person and moral manager: How executives develop a reputation for ethical leadership. California Management Review. 42(4), pp. 128-142. 
Thoroughgood, C. N., Padilla, A., Hunter, S. T., Tate, B. W. (2012). The susceptible circle: A taxonomy of followers associated with destructive leadership. The Leadership Quarterly. 23(5), pp. 897-917.

https://doi.org/10.1016/j.leaqua.2012.05.007

Toor, S., Ofori, G. (2009). Ethical leadership: Examining the relationships with full range leadership model, employee outcomes, and organizational culture. Journal of Business Ethics. 90, pp. 533-547. https://doi.org/10.1007/s10551-009-0059-3

Uramová, M., Kožiak, R. (2008). Regional disparities in Slovakia from the aspect of average nominal wage. $E+M$ Ekonomie a Management. 2, pp. 6-18.

Weaver, G. R., Reynolds, S. J., Brown, M. E. (2014). Moral intuition: Connecting current knowledge to future organizational research and practice. Journal of Management. 40(1), pp. 100-129. https://doi.org/10.1177/0149206313511272

Wright, T. A., Quick, J. C. (2011). The role of character in ethical leadership research. The Leadership Quarterly., 22, pp. 975-978. https://doi.org/10.1016/j.leaqua.2011.07.015
Xu, A. J., Loi, R., Ngo, H. (2014). Ethical leadership behavior and employee justice perceptions: The mediating role of trust in organization. Journal of Business Ethics. 134(3), pp. 493-504.

https://doi.org/10.1007/s10551-014-2457-4

Yazdani, N., Murad, H. S. (2015). Toward an ethical theory of organizing. Journal of Business Ethics. 127(2), pp. 399-417. https://doi.org/10.1007/s10551-014-2049-3

Yidong, T., Xinxin, L. (2013). How ethical leadership influence employees' innovative work behavior: A perspective of intrinsic motivation. Journal of Business Ethics. 116(2), pp. 441-455. https://doi.org/10.1007/s10551-012-1455-7

Yukl, G., Mahszd, R., Hassan, S., Prussia, G. E. (2013). An improved measure of ethical leadership. Journal of Leadership \& Organizational Studies. $20(1)$, pp. 38.48 . https://doi.org/10.1177/1548051811429352 